\title{
Students' Self-Directed Learning at Language University
}

\section{Aprendizaje autodirigido de los estudiantes en Language Univer- sity}

\author{
Anastasia Nikolaevna Yakovleva \\ M.K. Ammosov North-Eastern Federal University, 58, Belinskogo Str, 677000 Yakutsk, Russia \\ ORCID: https://orcid.org/0000-0002-4372-2789 \\ Irina Lvovna Savvina* \\ Institute of Foreign Philology and Regional Studies, M.K. Ammosov North-Eastern Federal \\ University, 58, Belinskogo Str, 677000 Yakutsk, Russia \\ ORCID: https://orcid.org/0000-0001-9731-3764 \\ Sakhaya Afanasievna Popova \\ Institute of Foreign Philology and Regional Studies, M.K. Ammosov North-Eastern Federal \\ University, 58, Belinskogo Str, 677000 Yakutsk, Russia \\ ORCID: https://orcid.org/0000-0002-5391-5242

\section{Galina Nikolaevna Sleptsova} \\ Institute of Foreign Philology and Regional Studies, M.K. Ammosov North-Eastern Federal \\ University, 58, Belinskogo Str, 677000 Yakutsk, Russia \\ ORCID: https://orcid.org/0000-0001-9240-7729
}

Received 06-14-20 Revised 08-10-20 Accepted 09-01-20 On line 09-25-20

*Correspondence

Email: sil26@list.ru
Cite as:
Yakovleva, A.N., Savvina, I.L., Popova, S.A., Sleptsova, G.N. (2020). Students' Self-Directed Learning at Language University. Propósitos y Representaciones, 8 (SPE3), e745. Doi: http://dx.doi.org/10.20511/pyr2020.v8nSPE3.745

(C) Universidad San Ignacio de Loyola, Vicerrectorado de Investigación, 2020. 


\section{Summary}

The article is devoted to the problem of self-directed learning of students of Language University. Self-organization is an integral characteristic of personality development. The authors studied the components of self-organization: self-assessment, some personal qualities, etc. Some peculiarities of self-organization of Language University students were revealed with the standardized questionnaires and questionnaires based on self-assessment. It turned out that students with high cognitive capacity have insufficient level of self-organization, low cognitive activity. Self-organization is formed in the process of independent work and autonomous learning. The authors consider the problem of educational autonomy development of students while learning foreign languages as an interdisciplinary problem, as a subject area of linguopedagogics. The research also studied methodological strategies for learning new vocabulary. The development of learning style activity depends on certain personal qualities related to native traits. The research about self-directed leaning of students is the basis for the development of pedagogical activities with the aim of developing the optimal style of educational methods. The content of this research is both theoretical and practical; we are creating conditions for effective cognitive activity.

Keywords: self-directed learning; students; autonomous learning; learning style activity, cognitive abilities.

\section{Resumen}

El artículo está dedicado al problema del aprendizaje autodirigido de los estudiantes de Language University. La autoorganización es una característica integral del desarrollo de la personalidad. Los autores estudiaron los componentes de la autoorganización: autoevaluación, algunas cualidades personales, etc. Algunas peculiaridades de la autoorganización de los estudiantes de la Universidad de Idiomas se revelaron con los cuestionarios estandarizados y los cuestionarios basados en la autoevaluación. Resultó que los estudiantes con alta capacidad cognitiva tienen un nivel insuficiente de autoorganización, baja actividad cognitiva. La autoorganización se forma en el proceso de trabajo independiente y aprendizaje autónomo. Los autores consideran el problema del desarrollo de la autonomía educativa de los estudiantes mientras aprenden lenguas extranjeras como un problema interdisciplinario, como un área temática de la lingüopedagogía. La investigación también estudió estrategias metodológicas para aprender nuevo vocabulario. El desarrollo de la actividad del estilo de aprendizaje depende de ciertas cualidades personales relacionadas con los rasgos nativos. La investigación sobre la inclinación autodirigida de los estudiantes es la base para el desarrollo de actividades pedagógicas con el objetivo de desarrollar el estilo óptimo de métodos educativos. El contenido de esta investigación es tanto teórico como práctico; estamos creando las condiciones para una actividad cognitiva eficaz.

Palabras clave: aprendizaje autodirigido; estudiantes; aprendizaje autónomo; actividad de estilo de aprendizaje, habilidades cognitivas.

\section{Introduction}

The problem of successful education of students is prevalent in any university, including language ones. The student develops a system of self-assessment and self-organization in the process of personal and professional development. Sometimes the 1st year students cannot pass the exams of the first session successfully, although they studied well at school. In such cases, students were not ready for university studies. Unlike school, university student, on the one hand, has relative freedom and independence during the semester. On the other hand, the student needs to organize his individual systematic work himself and the autonomous learning during the semester. 
During the studying years, the student develops a sphere of self-awareness and selfmanagement to a certain level. Self-organization is an integral characteristic of the personality development. There are motivation, education style, self-assessment, and certain personal qualities in the structure of self-organization. It is about a highly motivated attitude towards the study, ability to self-management and self-control, and the autonomous learning. Identification of self-organization features of students makes it possible to define a strategy of individual education in order to develop educational autonomy, makes a system of preparation for classes and exams, etc. The personality recognizing himself in various manifestations forms an adequate idea of himself, wants to change something in himself, to adjust, to improve. If a student can't cope with this activity, he is socially immature. The student knows himself on a certain side, gives himself an assessment, many self-assessments form a structure that represents an assessment in general.

I.S. Kon noted that self-assessments could be considered as direct components of "Image I" or as indicators of some unconscious personal qualities (Kon, 1978). B.G. Ananiev wrote that relations to oneself are the latest formation of individuality, but these qualities, which complete the structure of character, ensure the integrity of an individuality, "perform the functions of self-regulation and control of development, contributing to education and stabilization of the unity of the individuality" (Ananiev, 1969). N.S. Kopeina's works show how neurodynamic processes ensure educational success, emphasize the role of self-organization, consider optimal methods of preparation and passing exams depending on the properties of the nervous system (Kopeina, 1988). In general, data on the relationship between native traits and success in education differ in the researches. The most significant result of the research was the development of the concept of "individual style of education" by V.S. Merlin (1977). The development of an individual style of study ensures (within some limits) the same productivity, success of people with different native traits. Self-directed learning is developing in the process of individual work and autonomous learning.

Foreign and Russian scientists Bimmel P., Rampillon U., Solovova E.N., Ternovykh T.Y., et al. studied autonomous learning as a separate problem. The literature reveals a variety of definitions of autonomous learning. The authors may define it differently, but agree that it is about the capabilities and abilities of the student to define tasks and ways of learning and analyze their educational activities independently. A student wants to learn, he is interested, motivated to study, he is aware of his capabilities and try to overcome the limits of his capabilities (Rampillon, 1993, 1994). While considering the problems of developing educational autonomy in the teaching of foreign languages, it is necessary to consider both definitions of the concept of educational autonomy and related competences. This appears to be a difficult task, as the description of competences contributing to the development of educational autonomy appears to be a significantly difficult task. Much in this process cannot be directly observed, and the competences and strategies of the student can be immeasurably many, and this complicates their detailed description. Models and descriptors are created for educational autonomy, which are based on the theory of the phenomenon. The researches present different approaches to describing and modeling competences contributing to the development of educational autonomy. Both the competence of the student and the competence of the teacher are analyzed. Competences contributing to the development of educational autonomy of students are described as actions that the student performs in the self-governing educational process, although with the assistance of the teacher: definition of goals, selection of material, methods and strategies, etc (Holec, 1981). Models have also been developed that treat competences as foreign language learning strategies and also take into account, with direct strategies, axillary or management strategies that are important in self-directed learning process. The importance of metacognitive, social and affective strategies is also stressed (Oxford, 1990).

The concept of strategy is defined as central in cognitive educational psychology. Training autonomy is seen as a plan of (mental) actions to achieve the education goal (Bimmel, 1993). The students decide which educational material to study; What actions to do in learning 
activities; What materials and what tools to use; What learning strategies to use; Study individually or in cooperation with someone; How to allocate self-learning time; How to control success. We can say that student's learning autonomy is the ability of an individual to control his learning activity. The student's self-control over the results of his work systematically makes him adjusts it, uses effective educational strategies. E.P. Bacharova's research presents the organization of self-control while foreign language learning, which consists of three conditional stages, reflecting the process of transition from external forms of control to self-control. Initially, the teacher has a leading role in evaluation. At the second stage, students are involved in independent, mutual assessment activities during their group work. In this process, students alternately perform the control and evaluation functions of the teacher in relation to their fellow students. In the third stage there is an independent assessment of own activity or self-control. Training of students in self-control techniques facilitates their transition from the state of the object of external assessment and control to the state of the subject and control of their own educational activity. The combination of various forms of control and self-control: frontal, mutual and individual corresponds to 3 stages of work on educational material: "Introduction of educational information," Training in communication, "Practice in communication" (Bocharova, 1985).

The development of educational autonomy is impossible without the internal activity of the student himself, so one of the important tasks of study at the university is to manage the motivational sphere of the individual, increase interest in self-study and responsibility of the individual. Achieving these tasks is possible through increasing the internal self-organization of the individual. The definition of educational autonomy given by Holec $\mathrm{H}$. that autonomy is the ability to take responsibility for one 's own learning (Holec, 1981) is widely known. Internal activity of the individual, sense of responsibility for what is happening are of great importance in the process of development of educational autonomy of the individual. Responsibility is considered as a property of personality, the peculiarities of the manifestation of control locus are studied (Byzova, 1995; Kon, 1978). As the researchers believe "not only language is acquired in educational process", but also something else, more, which comes to the problems of attitude to language, developing of personal qualities of the student" (Galskova \& Gez, 2005).

The problem of development of educational autonomy of students in learning foreign languages is an interdisciplinary problem, where the issues of theory of education in the process of language learning are studied. These kinds of problems can be a subject area of linguopedagogics. The development of ideas of linguopedagogics is found in concepts of representatives of different branches of science. The problems of linguopedagogics are considered within the framework of linguopedagogical psychology (Rumyantseva, 2004), a psychotherapeutic approach to teaching foreign languages (Grishina, 2013). Linguopedagogics is going through a period of formation now, so it remains open to the questions of final specification of definitions of basic concepts and terms, its place among other scientific industries. Linguopedagogics is based on several fundamental scientific disciplines, such as pedagogy, psychology, acmeology, etc (Yakovleva \& Ikonnikova, 2017). The interdisciplinary nature of research within modern scientific knowledge is productive, especially in researches of education, where various factors interact. In foreign language education, the trends of integration of education and upbringing are particularly pronounced, when the individual is involved in foreign language culture, its socialization and education. These are one of the most important tasks of foreign language education, which should be reflected in modern concepts of foreign language education. Linguopedagogy focuses on the analysis and development of complementary methodological approaches. Linguopedagogy in the object of its study connects linguistic and pedagogical competences. Linguopedagogy, educational psychology and developmental psychologists have much in common; they have actually the same object, although each of them implements its own approach to it. The problems of developing educational autonomy of the individual are tasks that should be reflected in modern linguopedagogical concepts.

\section{Methods}


In our study, targeted students were philologists of the second and third year (56 students) of the Institute of Foreign Philology and Regional Studies of NEFU. The peculiarities of self-directed learning were studied. It included the study of personal properties. The student's high learning motivation depends on the competences already formed or the student's inclusion in the process of competences development. The main methods were observation: direct and indirect, questionnaires and interviews. Some individual characteristics were identified by R.B. Cattell's questionnaires.

A questionnaire to evaluate yourself, the ideal and one of the fellow students was used in order to identify the features of self-assessment and evaluation of fellow students. A questionnaire - scaling was used to identify the features of self-assessment. Students had to evaluate themselves, their ideal and one of the students on a scale from 0 to 5 by personal qualities: interpersonal skills, willpower, intellectual characteristics, autonomy, etc.

The study also used a questionnaire by N.S. Kopeina, which studies the learning activity style as one of the components of self-organization structure. It estimates two indicators: the strength of the nervous system and the regularity of educational activities. An interview was used to study educational strategies for learning new vocabulary. These strategies were chosen based on a preliminary survey of students. Memorizing words, according to students will be successful if they:

1. hear the word at the lesson;

2. use the Internet;

3. learn words alone in the silence;

4. learn words with mates;

5. learn words making a dictionary;

6. learn words by writing them down;

7. repeat words;

8. look for him in the dictionary;

9. look for a synonym to it;

10. write it on the card;

11. Other.

Then each student said the learning strategies he used to study and memorize words. The study of self-organization of students, by means of a questionnaire and standardized methods, is legal, as a more effective differentiated approach to students allows taking into account their positions in various spheres of personal activity. The researches note that a teacher often doesn't perceive a student as a holistic person, but only as a student who is better or worse at assimilating the educational program. Often teachers consider students who successfully cope with the educational program as prosperous personalities and students who study less successfully - prospectless. Students with good academic results are known to develop many positive qualities, but at the same time, the desire for high points is sometimes related to negative moments. High points lead to increased anxiety. Academic failures have a big impact on students. The feeling of emotional distress extends to all major areas of life. Life experience, based on educational failures is the basis for subjective limitation of prospects in various spheres of life. Therefore, the study of self-organization of students using scientific and practical methods: surveys, standardized methods contributes to the disclosure of personal properties, opportunities, levels of self-organization of students. Knowledge of self-organization levels allows relating them to the influence of individual pedagogical processes, which can contribute to the development of the optimal style of educational style. 


\section{Results}

The individual characteristics identified by Cattell's questionnaire indicate that a large proportion of the 2 year students are quite active and motivated. But they are tense, more anxious. The 3 year students are characterized by the optimal level of tension, quite active, but already less motivated.

Students, who have low-rated communicative qualities, corresponding to Cattell's questionnaire, also had low-rated intellectual characteristics, although, according to teachers and objective indicators, they were higher. Thus, students with low cognitive activity have high cognitive ability. These students rated their will qualities as low, which also corresponded to Cattell's questionnaire.

Comparison of average self-esteem scores, ideal score and mates score did not reveal any significant differences. The average self-esteem score was slightly lower than the ideal one. On average, self-esteem was lower than that fellow's student and ideal's for all interviewed students.

Kopeina N.S. studied the learning style (Kopeina, 1985). She thought, students with weak nervous system required special attention in the process of education. Kopeina's technique revealed a significant number of students with a weak nervous system (Rampillon, 1993, 1994). There were students who noted such factor as "laziness" among them.

Our survey of students showed that educational strategies in the study of vocabulary are believed to be effective.

\section{Discussion}

The results discovered that a large proportion of the $2 \mathrm{~d}$ year students were quite active and motivated, that proved their correct choice of a language university. Students have language abilities, interest in foreign languages learning. But they 're more tense, more anxious than the 3 year students. This can be explained by the fact that successful students are not sure that their position will continue, and less successful students are growing anxiety due to failed attempts to improve their situation.

The $3 \mathrm{~d}$ year students are characterized by the optimal level of tension, quite active, but already less motivated. This seems to indicate that they have established themselves in their positions, know their capabilities, but interest in study is declining due to expectations that have not been met.

It was found that students who rated their communicative qualities low, which corresponds to Cattell's questionnaire indicators, have low self-esteem and intellectual characteristics, although, according to teachers and objective indicators, they were higher. This can be explained by the fact that these students still have insufficient linguistic competence, and because of this they are passive in classes of foreign language and receive low rating points. Teachers know that these students can study well (show guesswork, cope with word semantics, etc.), but in general, students are not yet successful in classes. Thus, students with low learning activity have high cognitive ability.

A number of students have low self-organization combined with high cognitive abilities. Observations and parameters on Cattell's questionnaire showed that these students had a lack of will qualities. 
Although, the same students show interest and are quite successful in social and human science disciplines, especially if teachers of these subjects use non-traditional forms and methods of education. This suggests that innovative teaching methods should be used in teaching foreign languages. This also confirms the survey of students about difficulties in educational activities. $14 \%$ of surveyed students note inefficient foreign language class activities: "Boring grammar...» «Text retelling are not necessary"; «..It is not quite effective to do written tasks continuously, monotonously"; "I would like to have more classes in the form of games than in the form of exercises, during the game it is easier to remember the material"; "it is unnecessary to read materials in class again, which we made notes at home." At the same time, students offer effective tasks at foreign language classes, which they present in this way: "Speaking is more effective than performing exercises." "The most effective is a dialogue (teacher and students), it's not necessary to do a large amount of exercises", "Speaking, Oral Practice," More Speaking Assignments", "A greater emphasis should be placed on the vocabulary used by speakers to communicate in a foreign language"; "Continuous written assignments are not quite effective".

Thus, here students criticize teachers who do not sufficiently implement a communication and activity approach to education. But, apparently, this factor is not the main factor for academic failures of students. Self-organization implies an adequate understanding of human's capabilities. The trial found out that more than $50 \%$ of the students surveyed were not satisfied with the system of their independent work. Students point to the inability to systematic independent work during the semester, inability to mobilize their resources: "I'm sometimes lazy". The realization of opportunities of students depends primarily on them. However, it is important here whether the student is aware of his individual abilities, the specifics of his nervous system. The strength-weakness of the nervous system depends on the duration of active mental work, the type of nervous system requires a certain learning style.

A large proportion of students surveyed found themselves with a weak type of nervous system, many of them often refer it to laziness, lack of autonomy skills, not aware of their native traits, not bothering themselves with self-analysis and attempts to choose the optimal style of work. They have a long adaptation period at their first year. The main condition for their success is the mandatory development of systematic work, regime, development of the habit of mental work. However, they don't develop systemic, regular work, especially before exams. They need to take into account their native characteristics when organizing themselves and developing a learning activity style.

Educational strategies that students consider effective in learning vocabulary are those used with the teacher in classes. The data when students consider effective if they "learn words by writing them down," 'repeat words', "learn words alone in silence," coincides with the fact that a large proportion of students have a weak nervous system. They find it difficult to work in reading rooms, in hostel, they prefer to do homework in silence.

Thus, self-organization develops in the process of independent work and autonomous study. In modern conditions, the development and autonomy of the student, including learning the foreign languages, is very important in the education of students. Researchers are searching for methods of forming language competences. Now the priority in language education is the development of autonomous study, not only the management and control of study. The development of 'learning methods and strategies is important for foreign languages study, not just the development of foreign language teaching methods. So, the most important component of self-directed language learning is the educational autonomy of students, which is obvious.

\section{Conclusion}


Thus, a significant number of students surveyed showed insufficient level of self-directed learning. The development of educational style depends on certain personal qualities and is related to native traits. The study of self-organization of students is the basis for the development of pedagogical methods to develop a learning style.

The study of student's self-organization provides great opportunities to identify the features of a student 's personality and correct them. Teachers, tutors should focus on the development of self-awareness - the basis of self-organization in individual work with students. Students of junior courses need assistance in choosing the techniques of the study work appropriate to their individual characteristics.

But the special purpose of individual work with students is to help the student to manage himself, to form a high level of self-directed learning style.

\section{References}

Ananiev, B.G. (1969). Man as a subject of knowledge. L., P.315.

Bimmel, P. (1993). Lernstrategien im Deutschunterricht. Fremdsprache Deutsch, 8(1), 4-11.

Bocharova, E.P. (1985). Teaching students to self-control a means to enhance their educational success: thesis....candidate of pedagogical sciences. L.

Byzova, V.M. (1995). Control Locus among Representatives of Komi and Russian Ethnos. Psychological Journal, 6, 11-121.

Galskova, N.D., \& Gez, N.I. (2005). Theory of teaching foreign languages. Lingvodidactics and technique. M: AKADEMIA.

Grishina, E.A. (2013). Psychotherapeutic approach in teaching foreign languages. MGLU Gazette. Educational Sciences Series, issue \# 16 (676). MOSCOW, 125-135.

Holec, H. (1981). Autonomy in Foreign Language Learning. Oxford: Pergamon.

Kon, I.S. (1978). Discovering of "I." M.

Kopeina, N.S. (1985). Realize your capabilities. Methodological instructions for students on self-organization. L.

Kopeina, N.S. (1988). Self-organization and formation of individuality. Integral formation of individuality. Perm, 50-59.

Merlin, V.S. (1977). About Integral Study of Individuality. Problems of Integral Study of Individuality. Perm.

Oxford, R. (1990). Language Learning Strategies: What Every Teacher Should Know. Englewood Cliffs, NJ: Newbury House.

Rampillon, U. (1993, 1994). Autonomes Lernen im Fremdsprachenunterricht - ein Wiederspruch in sich oder eine neue Perspektive (in:) Die Neueren Sprachen - Heft, $455-466$.

Rumyantseva, I.M. (2004). Speech psychology and linguopedagogic psychology. M.: PER SE, Logos.

Ternovykh, T.Yu. (2007). The method of forming strategies of autonomous educational activity among students-freshmen in work with foreign-language text. thesis.... candidate of pedagogical sciences. M.

Yakovleva, A.N., \& Ikonnikova, A.N. (2017). Teaching a second foreign language as a linguistic and pedagogical problem. 4-th International Multidisciplinary Scientific Conference on Social Sciences and Arts SGEM Conference/ Bulgaria, 977-981. 